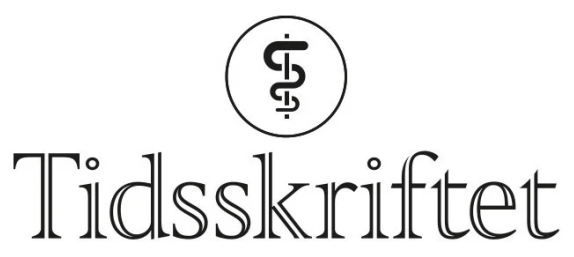

DEN NORSKE LEGEFORENING

\title{
S. Vambheim og medarbeidere svarer
}

\author{
KOMMENTAR \\ SARA MAGELSSEN VAMBHEIM \\ s.m.vambheim@medisin.uio.no \\ Sara Magelssen Vambheim er postdok ved Avdeling for smertebehandling, Oslo universitetssykehus.
}

\section{AUDUN STUBHAUG}

TONE MARTE LJOSÅ

\section{LARS-PETTER GRANAN}

Ingen av forfatterne har oppgitt noen interessekonflikter.

Vi er takknemlige for at Norsk forening for smertemedisin (NFSM) eksplisitt engasjerer seg i opioiddebatten. I sin kommentar til vårt innlegg (1) er de enige i de faktiske forhold vi påpeker, men liker ikke vinklingen og overskriften.

Vi er enige om at opioidforbruket i Norge er stabilt. Til tross for liberaliserende endringer i blåreseptordningen er norske legers forskrivning uendret over mange år. Når det slås stort opp i media at oksykodonforbruket er mangedoblet og representerer en opioidepidemi, så er det en «tabloid» feilinformasjon. For den relativt sett store økningen i

oksykodonforskrivning skyldes at preparatet har kort fartstid og har erstattet andre morfinlignende stoffer uten $\emptyset \mathrm{kt}$ totalforbruk av opioider. Vi bør få lov til å gi norske leger korrekt informasjon, uten at dette skal karakteriseres som bagatellisering av problemet med feil bruk av opioider.

Vi er ikke uenige i at arbeidet med å redusere feil bruk av opioider må fortsette. Norsk forening for smertemedisin har feiltolket vår vinkling. Når vi skriver at endringen i blåreseptordningen «ikke krever at det oppgis diagnose eller smerte-årsak», så er det ikke en påstand, men et faktum som vi problematiserer. Vi påpeker at dette står i kontrast til kravet for mange andre preparater som er gode ikke-opioide medikamentelle alternativer ved langvarige smerter, som for eksempel okskarbazepin (Trileptal) og duloksetin (Cymbalta). For disse preparatene er det krav til diagnose, og blåreseptdekning avslås hvis bruken ikke er innenfor markedsføringstillatelsen. Dette gjelder mange smertepasienter som får avslag fra Helfo på dekning av disse preparatene, mens opioider vil kunne dekkes for de samme pasientene uten krav til diagnose eller smerteårsak. Vi påpeker dermed at det er industriens søknad om markedsføringstillatelse som styrer Helfo, ikke fagmiljøets konsensus. Hadde det vært opp til oss, kunne det vært strengere krav til blåreseptdekning 
av opioider og mer liberale krav til flere andre preparater i tråd med vår nylig publiserte metodebok (2). Dette poenget har dessverre gått Norsk forening for smertemedisin hus forbi. Ved deres ensidige fokus på opioider ser det ut til at pasienten er tapt av syne. De hadde $\emptyset$ nsket at vi bare skulle problematisere opioidbruk slik nasjonale retningslinjer og KUPP-kampanjen allerede gjør, og avslutter med ønsket om at vi skal håndtere pasienter «i henhold til blåreseptordningen for analgetika». Vi er slettes ikke fornøyd med denne ordningen, og gjentar derfor vår avslutning som ikke synes lest: «Blåreseptordningen bør heller endres slik at fagmiljøets konsensus avgjør hva som er nyttig behandling, og hva som bør refunderes, framfor hva industrien finner ønskelig og mulig å søke markedsføringstillatelse for».

Når det gjelder den «tabloide» overskriften i vårt innlegg, så var den anbefalt av Tidsskriftet og således i henhold til deres redaksjonelle linje. Kanskje har den tjent sin hensikt, å få leserne interessert i å lese innlegget?

\section{LITTERATUR}

1. Stubhaug A, Ljoså TM, Granan LP et al. Opioidkrisen kan avblåses. Tidsskr Nor Legeforen 2021; 141. doi: 10.4045/tidsskr.21.0621. [PubMed][CrossRef]

2. Oslo universitetssykehus. Regional kompetansetjeneste for smerte. Metodebok for smertebehandling (Versjon 1.0). 2021. https://oslo-universitetssykehus.no/seksjon/Regionalkompetansetjeneste-forsmerte/Documents/Metodebok\%2olangvarige\%2osmerter\%2oOUS\%2Ov1.o.pdf Lest 22.11.2021.

Publisert: 13. desember 2021. Tidsskr Nor Legeforen. DOI: 10.4045/tidsskr.21.0819

(C) Tidsskrift for Den norske legeforening 2023. Lastet ned fra tidsskriftet.no 26. april 2023. 